\title{
Top Management Commitment Towards Implementation of Total Quality Management (TQM) in Construction Companies in Nakuru County-Kenya
}

\author{
Bonventure Wesonga Oruma ${ }^{1}$, John Momanyi Mironga ${ }^{2}$, Benard Onyango Muma ${ }^{3}$ \\ ${ }^{1}$ Department of Education and External Studies, University of Nairobi, Nairobi, Kenya \\ ${ }^{2}$ Department of Geography, Egerton University, Nakuru, Kenya \\ ${ }^{3}$ Faculty of Commerce, Department of Accounting, Finance and Management Science, Egerton University, Nakuru, Kenya \\ Email address: \\ wesongaoruma@gmail.com (B. W. Oruma),john.mironga@gmail.com (J. M. Mironga), mumabenard@gmail.com (B. O. Muma)
}

\section{To cite this article:}

Bonventure Wesonga Oruma, John Momanyi Mironga, Benard Onyango Muma. Top Management Commitment Towards Implementation of Total Quality Management (TQM) in Construction Companies in Nakuru County-Kenya. International Journal of Economics, Finance and Management Sciences. Vol. 2, No. 6, 2014, pp. 332-338. doi: 10.11648/j.ijefm.20140206.15

\begin{abstract}
The construction companies are faced with a lot of challenges especially in the choice of management approaches that they use to produce products that continuously meet customer needs and expectation in regard to quality issues. One of the management approaches being used to achieve continuous quality improvement in the construction industry is Total Quality Management (TQM). This study sought to determine the factors influencing implementation of TQM in construction companies in Nakuru County. Questionnaires and structured questionnaires involving the participation of over 15 construction companies were used as the main tools for this study. The findings of this study revealed that Top Management Commitment is a critical factor affecting the implementation of TQM in construction companies in Nakuru County. The study thus recommends that construction industry sector give this factor special consideration when developing their TQM approaches. The study further recommends that studies be done to explore other factors other than top management commitment affecting the implementation and success of TQM.
\end{abstract}

Keywords: Top Management Commitment, Total Quality Management, Construction Industry in Nakuru County

\section{Introduction}

The current business environment requires that an organization remains sustainable in its operations and produces products that continuously meet customer needs and expectations (Muma et al., 2014). One of the management approaches that can be used to achieve continuous quality improvement is Total Quality Management (TQM). The concept of TQM came into existence in 1970s when evolution of quality took a strategic shift from Quality Control to a strategic approach of quality to take care of the growing attention concern on quality. From then, quality management has evolved through Quality Inspection, to Quality Control, to Quality Assurance then to the current Total Quality Management (Kenya Institute of Management, 2009).

Globally, a number of organizations have adopted quality initiatives. Toyota company for instance developed the philosophies of 'customer first' and 'quality first' and set up quality assurance systems across various departments (Omware, 2013). In Africa, TQM implementation of TQM is evident in countries such as Zambia, where with the help of Japan International Cooperation Agency (JICA), the government adopted fishbone and quality control cycles to enhance tax collection (Jica, 2012). In Kenya, many organizations, especially in service industry have embraced quality management techniques such as ISO standards and TQM programs. For instance, all government parastatals and Public Universities in Kenya are currently ISO certified (Kenya Bureau of Standards, 2014)

\subsection{Research Objectives}

The study was guided by the following specific objectives:

1. To investigate the effect of Top Management Leadership on implementation of TQM in Construction Industry in Nakuru County

2. To investigate the effect of provision of critical resources 
on implementation of TQM in Construction Industry in Nakuru County

3. To investigate the effect of management involvement on implementation of TQM in Construction Industry in Nakuru County

\subsection{Research Hypothesis}

This study tested the following hypothesis;

Ho1: Top Management Leadership has a negative effect on implementation of TQM in Construction Industry in Nakuru County

Ho2: Provision of critical resources has a negative effect on implementation of TQM in Construction Industry in Nakuru County

Ho3: Management involvement negatively affects implementation of TQM in Construction Industry in Nakuru County

\subsection{Conceptual Framework}

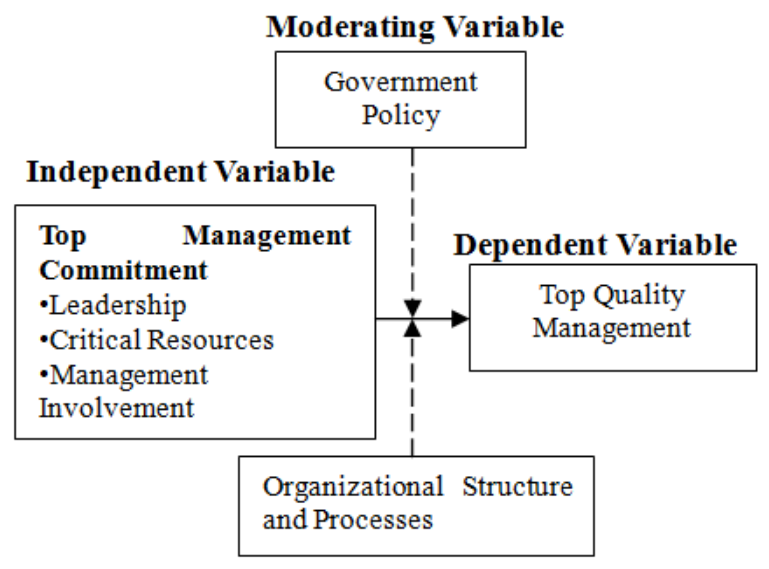

Intervening Variable

Figure 1. Conceptual Framework

\section{Literature Review}

\subsection{Top Management Commitment}

The American Society of Quality Control considered quality a very subjective term as every person has his or her own definition of the term. Different authorities in quality management have defined quality in different ways. For instance, Juran defined quality as "Fitness for use" of a product; Crosby defined it as "Conformance to requirement" by a product while to Taguchi, it is the "Variation from target" (Kenya Institute of Management, 2009). Quality Management generally is the process of ensuring that a product (good or service) continuously meet and even exceed customer expectations and can be generally looked at as a business management approach that attempts to maximize organizational competitiveness through continuous improvement of its products, services, work force, processes, and environment. It is an approach aimed at continuously improving the competitiveness, effectiveness and flexibility of the entire organization through total involvement of everyone in the organization led by the management (Kasongo \& Moono, 2010).

The concept of TQM came into existence in 1970s when evolution of quality took a strategic shift from Quality Control to a strategic approach of quality to take care of the growing attention on quality. From then, quality management has evolved through Quality Inspection, to Quality Control, to Quality Assurance then to the current Total Quality Management (Kenya Institute of Management, 2009).

\subsection{Total Quality Management (TQM)}

The overall objective of TQM is to ensure continuous improvement in the organization's people, systems, processes and environment so as to achieve improved customer service and increased profits through efficiency and effectiveness in the entire organization (Bahri et al., 2012). Implementation of TQM is associated with benefits to both the organization and its clients, it is therefore regarded a double sided competitiveness tool. It is important to note that any organization can implement TQM irrespective of the size or operations. However, the success of the implementation process depends on how well the organization understands the process and the strategies adopted. One guiding principle in implementation of TQM is that the process must be organization wide; everyone and every function in the organization must be involved in the process with the management taking a leading role (Schuurman, 1997)

Implementation of TQM is an elaborate process that takes time and resources. It is a process that must be initiated and managed by the top management. The top management must make available all critical resources required as well as the organizational structure and culture required. The process must focus on finding out, meeting and exceeding customer needs and expectations through total involvement of everyone in the organization and through continuous improvement. This process requires exceptional skills and team work that call for continuous employees training and development (Oluwatoyin, 2008)

It is important to note that there are factors that may inhibit successful implementation of TQM. Arshida \& Agil (2012) refer to them as barriers of TQM implementation. These factors include; lack of top management commitment which is associated with lack of critical resources and poor leadership leading to poor employee empowerment and motivation, poor or weak organizational vision and plan statement that dilutes employee's efforts in quality programs. Another important factor is government influence that is associated with bureaucracy and slow systems. Lack of favorable quality policy or low government support of quality programs makes it a challenge to adopt and implement quality initiatives.

\subsection{Empirical Literature}

Top Management plays a critical role in any key business decision. Consequently, the success of any critical decision 
made in an organization is highly dependent on top management support and commitment (Zakuan et al., 2012). Quality issue has become of great importance to every organization and no management can afford to let nature take its course when it comes to quality. The top management must play a leading role by making available the critical resources, establishing an organization wide quality policy that is well communicated to all stakeholders, establishing a quality management structure and managing the entire process through close monitoring and evaluation. This must be supported by an organization culture and climate of open cooperation and team work among stakeholders in quality management (Sharp et al., 2000).

As cited by Zakuan et al (2012), Deming (1986) urges that managers must institute leadership to usher the quality transformation process. Parameshwar and Srikantia (2000) discussed two types of leadership: transformational leadership and transactional leadership. Transformational leadership is leadership that is based on an ideologically anchored vision while transactional leadership is based on reward control mechanisms and emphasizes on clarification of followers roles and goals and the way the desired outcome will follow after achievement of the set goals. Champions of innovation tend to exhibit transformational leadership behavior; they try to initiate influence through calculated tactics in their work environment.

Arshida \& Agil (2012) points out top management commitment as an essential element for ensuring successful TQM implementation. The top management must be on the fore front of the quality management process starting from the initial stages. According to Omware (2012), adoption of TQM for the first time is associated with development of new organizational policy, new procedures and new tools that must be learned. TQM is an organizational change process that is often associated with instability, confusion, and employees' resistance and must be carefully initiated through consistent management involvement. This was consistent with Samir (2003) that top management must develop clear quality mission and goals and identify quality values and communicate them to all employees. They must put in place a proper quality planning process, and a good quality management structure to ensure successful implementation

A review conducted by Zakuan et al. (2012) on critical success factors of TQM implementation in Higher Education Institutions shows that the success of an institution depends on its quality management strategy on how it identifies, classifies, analyzes, and reacts to the changes in quality requirements. This is consistent with the findings of Sharp et al. (2000) on their study on factors affecting successful implementation of ISO 9001: 2000 and Kasongo \& Moono (2010)'s study on factors that lead to successful implementation of TQM that identified management strategy as one of the critical factors in implementing quality systems. Baidoun (2003) also conducted an empirical study on critical factors of TQM in Palestinian organizations and found out that top management commitment and involvement demonstrated by: development of clear organization mission, development of quality policy and values, setting of realistic quality goals, proper planning on quality management and creating quality management structure creates quality awareness and improve implementation of quality management systems. In addition, quality management philosophy makes it easy to implement quality programs (Murphey, 2009).

\subsection{Construction Sector in Kenya}

The Kenyan construction sector is under the Ministry of Public Works and National Construction Authority and covers work done on buildings and infrastructures. According to Kenya Private Developers Association, the major challenges facing construction companies in Kenya are Capital and dealing with the strict quality standards and dynamic customer demand. Quality assurance in the sector has in the past been left to the Local Authorities. Most of these authorities lack the capacity to handle this issue and in most instances leave it to Public Health Officers. To deal with the challenge of quality, most contractors have resorted to conservative approach to the market and prefer working for clients with similar thinking patterns. The government on the other hand, through the Ministry of Public Works has been holding workshops that bring together stakeholders in the sector to deliberate on the challenges. They envisaged that it is important that proper understanding to quality is achieved such that every construction company is able to achieve at organizational level.

\section{Methodology}

\subsection{Research Design}

This was a correlational study. A correlational design involves delineation of the important variables associated with the research problem (Sukaran, 2010) and investigates one or more characteristics of a group to discover the extent to which the characteristics vary together (Simon, 2011; Kothari, 2004). The study sought to establish the factors that influence implementation of TQM. In addition, this was a survey, a is associated with a guided and quick collection, analysis and interpretation of observation (Mugenda and Mugenda, 1999).

\subsection{Target Population}

The target population of this study comprised of the construction companies in Nakuru County while the respondents were the employees of the Construction Companies in Nakuru County. There are 54 construction companies in Nakuru (County National Construction Authority Nakuru, 2014).

\subsection{Sample Size and Sampling Procedure}

Simple random sampling was used to select 15 of the construction companies. Simple random sampling is a sampling technique in which all possible samples of ' $n$ ' 
objects have equal likelihood of being selected (Frerichs, 2008). Due to financial and time constraints, 15 construction companies were selected. On the other hand, respondents sample was determined using stratified random sampling technique to ensure that different groups of a population are adequately represented in the sample. Stratified sampling divides the population into homogenous groups such that the elements within each group are more alike than the elements in the population as a whole (Nachmias and Nachmias, 2008). Yamane (1967) provided a simplified formula to calculate sample sizes. The sample for this study comprised selected employees from all levels and departments of the selected organizations. This is because implementation of TQM is everyone's business in the organization. To obtain the sample size, the study used the Yamane's formula as shown below;

$$
n=\frac{\mathrm{N}}{1+\mathrm{N}(\mathrm{e})^{2}}
$$

Where;

$\mathrm{n}=$ the desired sample size

$\mathrm{e}=$ probability of error

$\mathrm{N}=$ estimate of the population size.

The distribution of respondents is as shown in table 1

Table 1. Proportionate Distribution of Employees in their Departments

\begin{tabular}{llll}
\hline No & Company & $\begin{array}{l}\text { Population } \\
\text { (N) }\end{array}$ & $\begin{array}{l}\text { Sample } \\
\text { (n) }\end{array}$ \\
\hline 1. & Reliable Concrete Works & 45 & 40 \\
2. & Anduru Construction Co Ltd & 14 & 10 \\
3. & KalaluBuilding Contractors & 20 & 19 \\
4. & Mawe Construction Co. & 21 & 19 \\
5. & Jagir Singh Contractors Ltd & 19 & 14 \\
6. & Libix Construction Ltd & 16 & 14 \\
7. & Recco Builders Ltd & 15 & 14 \\
8. & Spion Construction Company & 19 & 14 \\
9 & Pimka Construction Company & 13 & 10 \\
10. & Lawane Contractors LTD & 14 & 10 \\
11. & KolKol Construction Company & 16 & 14 \\
12. & Real Mark Construction LTD & 17 & 14 \\
13. & Emuwan Construction Ltd & 18 & 14 \\
14. & Jimwa Construction \& Services LTD & 16 & 14 \\
15. & Multi - Span Builders (K) LTD & 13 & 230 \\
\hline & Total & 276 & 10 \\
\hline
\end{tabular}

\subsection{Data Collection}

Primary data was collected regarding top management commitment and TQM. The respondents for this study were employees from various functional areas in the organizations. Data was collected using structured questionnaires which were self-administered. A preliminary test was done on the data collection tools and procedures to identify likely problems. The researcher took necessary actions in time before the actual data collection. This test was conducted at Gibralter Property Developers in Kisumu, whereby twenty questionnaires were administered to the employees in the respective departments. The filled questionnaires were later checked for comprehensiveness and consistency. Validity determines whether the research items truly measure what they are intended to measure or how factual the research results are (Golafshani, 2003). To test content validity (extent to which the sample is a representative of the population), experts opinion were sought. The research items or questions in the questionnaire were developed to represent dimensions of each variable in the research. The data collected from the pilot study were subjected to factor analysis to test construct validity. Reliability is the extent to which results of a study are consistent over time and there is an accurate representation of the total population under study (Golafshani, 2003). Reliability analysis aims at finding out the extent to which a measurement procedure will produce the same result if the process is repeated over and over again under the same conditions (Toke et al., 2012). Cronbach alpha coefficient was computed using SPSS and produced a value of 0.806 as shown in table 2 . This value was compared with the threshold of 0.7 to ensure there is reliability. The Cronbach alpha coefficient value above 0.6 shows that the measurement procedure is reliable (Toke et al., 2012)

Table 2. Reliability Statistics

\begin{tabular}{ll}
\hline Cronbach's Alpha & N of Items \\
\hline .806 & 49 \\
\hline
\end{tabular}

\subsection{Data Analysis Technique}

The data collected was coded, and analyzed through SPSS (statistical package for social sciences) version 20. Correlation analysis was conducted to establish the influence of top management commitment on implementation of TQM.

\subsection{Ethical Considerations}

The researcher sought authorization from the management of the Construction Companies in Nakuru County before carrying out the research. All information obtained in this research was strictly used for academic purposes and respondents were assured of the confidentially of information given where necessary.

\section{Results and Discussion}

To establish the relationship between individual indicators of top management commitment and implementation of TQM, correlation analysis was conducted. Multiple regression analysis was conducted to establish the overall effect of top management commitment on implementation of TQM. The results were as shown in the tables below. 
Table 3. Top Management Leadership and TQM Implementation

\begin{tabular}{llll}
\hline & & Leadership & TQM Implementation \\
\hline \multirow{3}{*}{ Leadership } & Pearson Correlation & 1 & $.566^{* *}$ \\
& Sig. (1-tailed) & & .002 \\
& $\mathrm{~N}$ & 25 & 25 \\
\multirow{2}{*}{ Total Quality Management } & Pearson Correlation & $.566^{* *}$ & 1 \\
& Sig. (1-tailed) & .002 & 25 \\
\hline
\end{tabular}

**. Correlation is significant at the 0.01 level (1-tailed).

Table 3 shows the correlation between top management leadership and implementation of TQM. The Pearson's correlation value of 0.566 indicates a strong positive relationship between top management leadership and implementation of TQM. One tailed significant test was used to test the significance of the relationship. The significance value of 0.002 shows that the relationship between top-management leadership and implantation of TQM is statistically significant. The findings of this study are in agreement with the arguments of Deming (1986) that managers must institute leadership to usher the quality transformation process and Parameshwar and Srikantia (2000)'s arguments that transformational and transactional leadership is key in implementation of TQM.

Table 4. Critical Resources and TQM Implementation

\begin{tabular}{llll}
\hline & & Critical Resources & TQM Implantation \\
\hline \multirow{4}{*}{ Critical Resources } & Pearson Correlation & 1 & .318 \\
& Sig. (1-tailed) & & .061 \\
& N & 25 & 25 \\
\multirow{2}{*}{ Total Quality Management } & Pearson Correlation & .318 & 1 \\
& Sig. (1-tailed) & .061 & 25 \\
\hline
\end{tabular}

From table 4, the Pearson's correlation value of 0.318 shows that the relationship between provisions of critical resources has positive but relatively weak relationship. Further, the significant value of 0.061 indicates that the relationship is not statistically significant. These findings are in agreement with the findings of Kasongo and Moono (2010) which revealed that critical resources such as financial resources and human resources facilitate adoption of quality management initiatives and activities.

Table 5. Top Management Involvement and TQM Implantation

\begin{tabular}{llll}
\hline & & Top Management Involvement & TQM Implantation \\
\hline \multirow{3}{*}{ Top Management Involvement } & Pearson Correlation & 1 & $.602^{* *}$ \\
& Sig. (1-tailed) & & .001 \\
& $\mathrm{~N}$ & 25 & 25 \\
\multirow{3}{*}{ Total Quality Management } & Pearson Correlation & $.602^{* *}$ & 1 \\
& Sig. (1-tailed) & .001 & 25 \\
\hline
\end{tabular}

**. Correlation is significant at the 0.01 level (1-tailed).

Table 5 shows the correlation between top management involvement and implementation of TQM. The Pearson's correlation value of 0.602 indicates a strong positive relationship between top management involvement and implementation of TQM. The significant value of 0.001 indicates that the relationship is statistically significant. These findings concur with the results of Baidoun (2003) that revealed that management involvement demonstrated by: development of clear organization mission, development of quality policy and values, setting of realistic quality goals, proper planning on quality management and creating quality management structure creates quality awareness and improve implementation of quality management systems.

Table 6. Combined Effect of Top Management Commitment on Implementation of TQM

\begin{tabular}{lllll}
\hline Model & R & R Square & Adjusted R Square & Std. Error of the Estimate \\
\hline 1 & $.618^{\mathrm{a}}$ & .382 & .294 & .0395 \\
\hline
\end{tabular}

a. Predictors: (Constant), Management Involvement, Critical Resources, Leadership

Table 6 shows the combined effect of top management commitment and implementation of TQM. The R square value 
of 0.382 shows that top management commitment positively affects implementation of TQM by $38.2 \%$. These findings can be supported by the findings of Arshida \& Agil (2012) that top management commitment is an essential element for ensuring successful TQM implementation and as such, top management must be on the fore front of the quality management process starting from the initial stages

Table 7. Significant test on the Effect of Top Management Commitment on Implementation of TQM

\begin{tabular}{llllll}
\hline Model & & Sum of Squares & Df & Mean Square & F \\
\hline \multirow{3}{*}{1} & Regression & .020 & 3 & .007 & $.016^{\mathrm{b}}$ \\
& Residual & .033 & 21 & .002 & \\
& Total & .053 & 24 & & \\
\hline
\end{tabular}

a. Dependent Variable: Total Quality Management

b. Predictors: (Constant), Management Involvement, Critical Resources, Leadership

Table 7 shows the significant test on the effect of top management commitment on implementation of TQM. Significance value $(\mathrm{p})$ of 0.016 gives the test on the entire model. It shows that the overall effect of top management commitment on implementation of TQM is not statistically significant.

\section{Conclusions}

The following conclusions were evident from the study. Firstly, top management leadership has statistically significant positive effect on implementation of TQM. When right leadership is provided by management in quality management initiatives, employees look at quality management as any other strategic management issue in the organization. The secondly was made that provision of critical resources required in the implementation of TQM positively affects implementation of TQM. Availability of critical resources enhances capacity of the involved employees in adopting quality management programs. Lastly, it was evident that top management involvement in quality management programs and activities positively affects implementation of TQM. Involvement of management in quality management creates a participative environment in the organization which is very important in implementation of TQM. An overall conclusion was made that Top Management Commitment influences implementation of TQM. The study revealed that top management commitment is a critical factor in implementation of TQM in construction industry in Nakuru County. This means that with increased top management commitment in terms of providing leadership, providing critical resource and getting involved in the implementation of TQM, the implementation of TQM is likely to be more successful.

\section{Recommendations}

From the study, it was evident that top management commitment positively affects implementation of TQM. This study therefore recommends that construction companies as well as other organizations who are implementing TQM take strategic measures in ensuring top management participation and commitment to quality initiatives. This study further recommends that top managements commit themselves in providing leadership and key resources needed in quality management.

\section{References}

[1] Arshida M. M. and Agil S. O. (2012). Critical Success Factors for Total Quality Management Implementation Within the Libyan Iron and Steel Company. Tun Abdul Razak University, Graduat School of Business

[2] Bahri S., Hamzah D. and Yusuf M. R. (2012). Implementation of Total Quality Management and Its Effect on Organizational Performance of Manufacturing IndustriesThrough Organizational Culture in South Sulawesi, Indonesia. Journal of Business and Management 5(1) 10-24

[3] Baidoun S. (2003). An Empirical Study of Critical Factors of TQM in Palestinian Organizations. Logistics Information Management 16 (2), 156-171

[4] Frenrichs, (2008) Simple Random Sampling

[5] Golafshani, N. (2003).Understanding Reliability and Validity in Qualitative Research. The Qualitative Report 8 (4)

[6] Jamali G., Ebrahimi M and Abbaszadeh A. M. (2010). TQM Implementation: An Investigation of Critical Success Factors. International Conference on Education and Management Technology

[7] Kenya Institute of Management (2009). Total Quality Management: Theory, Concepts and Practice. Macmillan Publishers

[8] Kothari, C.R. (2008). Research Methodology-Methods and Techniques. New Delhi: New Age International (P) Limited Publishers.

[9] Moono M. and Kasongo K. (2010). Factors That Lead to a Successful TQM Implementation: A Case Study on the Zambian Tourism Industry

[10] Mugenda, M.O. and Mugenda, G.A. (1999). Research Methods: Quantitative and Qualitative Approaches. Nairobi: Central Graphics Services.

[11] Muma, B. M., Nyaoga, R. B., Matwere, R. B. and Nyambega, E. (2014). Green Supply Chain Management and Environmental Performance among Tea Processing Firms in Kericho CountyKenya. International Journal of Economics, Finance and Management Sciences. 2 (5)

[12] Murphey J. F. (2009). Total Quality Management: An Assessment of Implementation in Florida's Municipal Police Agencies. 
[13] Oluwatoyin A. and Oluseun A. (2008).Total Quality Management. A test of the Effect of TQM on Performance and Stakeholder Satisfaction. Blekinge Institute of Technology, School of Management

[14] Omware Q. (2012). Determinants of Quality Management Practices. University of Nairobi

[15] Parameshwar S., Srikantia P. and Case S. S. (2000). Factors affecting implementation of TQM in Knowledge Work Enviroments: An Intergrated Framework. Weather head School of Management

[16] Salaheldin S. I. (2009). Critical Success Factors for TQM Implementation and their Impact on Performance of SMEs. International Journal of Productivity and Performance Management. 58 (3), 215-237

[17] Schuurman. H. (1997). Quality Management and Competitiveness. The diffusion of the ISO 9000 Standards in Latin America and Recommendations for Government Strategies. UNITED NATIONS Division of Production, Productivity and Management Santiago, Chile, 1997

[18] Wali S. and Boujelbene V. (2011). Cultural Influences on TQM Implementation and Financial Performance in Tunisian Firms
[19] Zakuan N., Muniandy S., Saman N. Z. and MdArif M. S. (2012). Critical Success Factors of Total Quality Management Implementation In Higher Education Institution: A Review, International Journal of Academic Research in Business and Social Sciences 2(12)692-699

[20] JICA's (2013). Help, 'Kaizen' Is Being Widely Adopted in frica. Retrieved, March, 14, 2014 from http://www.jica.go.jp/english/news/field/2013/130529 1.html

[21] Sony (2013). Product Quality and Quality Management Retrieved on March 14, 2014 from http://www.sony.net/SonyInfo/csr_report/quality/mana ement/

[22] The Contractor (2012). Quality in Construction. Retrieved on March 14, 2014 from $\mathrm{http}: / /$ theconstructor.org/constrution/quality

[23] Kenya Bureau of Standards, 2014. Certification. Retrieved on 1st December, 2014 from: https://www.google.com/search?q=kbs\&ie=utf- $8 \&$ oe=utf- $8 \& a$ $\mathrm{q}=\mathrm{t} \& \mathrm{rls}=$ org.mozilla:en-US:official\&client $=$ firefox-a\&channe $\mathrm{l}=\mathrm{fflb} \# \mathrm{rls}=$ org.mozilla:en-US:official\&channel=fflb\&q=kenya +bureau + of + standards 